\title{
Profil Lendir Serviks Rusa Timor (Cervus timorensis) Betina yang Mendapat Suplementasi Mineral pada Tiap Fase Berahi
}

\author{
Cervical Mucus Profile on Female Timor Deer (Cervus timorensis) with Mineral \\ Supplementation within Each Estrous Phase
}

W. Purwaningsih, D. Samsudewa, dan Y. S. Ondho

Fakultas Peternakan dan Pertanian Universitas Diponegoro, Semarang. Email : wiwikpurwaningsih95@gmail.com

\begin{abstract}
The aims of this research were to observed the effect of zinc $(\mathrm{Zn})$, magnesium $(\mathrm{Mg})$ and selenium $(\mathrm{Se})$ to the abundance, color and spinnbarkeit of cervical mucus. The materials used were 10 Timor deers with BCS (Body Condition Score) of 2-3.25, poel 2 and had different estrous phase. The parameters observed were the abundance, color and spinnbarkeit of cervical mucus. The data of abundance and color of cervical mucus were analyzed by Mann Whitney U-test and the data of spinnbarkeit were analyzed by t-test. The treatments were zinc ( $\mathrm{Zn})$, selenium (Se) and magnesium (Mg) supplementation (T1) on mineral block form and control (T0). The results showed that $\mathrm{Zn}$, $\mathrm{Se}$, and $\mathrm{Mg}$ supplementation had no significant effect $(\mathrm{P}>0.05)$ to the abundance, color and spinnbarkeit of cervical mucus Timor deer on estrous phase. It was caused by the high zinc level on feed, so the cervical mucus profile had no difference between $\mathrm{T} 0$ and $\mathrm{T} 1$.
\end{abstract}

Key words : mineral supplementation, cervical mucus, Timor Deer

\begin{abstract}
ABSTRAK
Penelitian ini bertujuan untuk mengetahui pengaruh mineral Zink (Zn), magnesium (Mg), selenium (Se) terhadap kelimpahan, warna dan spinnbarkeit lendir serviks. Materi yang digunakan adalah 10 ekor rusa yang memiliki BCS (Body Condition Score) $2-3,25$, poel 2, pernah melahirkan, sehat secara fisik dan memiliki panjang fase berahi yang berbeda-beda. Parameter yang diamati meliputi kelimpahan, warna dan nilai spinnbarkeit lendir. Analisis data yang digunakan adalah Mann Whitney U-test pada hasil pengamatan kelimpahan dan tingkat kekeruhan lendir serta T-test pada nilai spinnbarkeit lendir. Perlakuan yang diberikan berupa suplementasi mineral Zink (Zn), Selenium (Se) dan Magnesium (Mg) dalam bentuk mineral blok (T1) dan kontrol (T0). Hasil penelitian menunjukan bahwa suplementasi mineral $\mathrm{Zn}$, Se dan Mg tidak menunjukan perbedaan yang nyata $(\mathrm{P}>0,05)$ terhadap kelimpahan, warna dan spinnbarkeit lendir serviks rusa timor betina pada fase berahi. Hal tersebut terjadi karena kadar Zinc (Zn) dalam pakan yang diberikan sudah tinggi, sehingga tampilan profil lendir serviks pada T0 tidak berbeda dengan T1.
\end{abstract}

Kata Kunci : Suplementasi Mineral, Lendir serviks, Rusa Timor

\section{PENDAHULUAN}

Rusa, sebagai salah satu jenis satwa harapan di Indonesia tentunya dipelihara dengan tujuan untuk memperoleh peningkatan populasi secara signifikan. Untuk mencapai tujuan tersebut, maka penangkaran rusa hendaknya memperhatikan manajemen reproduksi rusa yang ditangkarkan, salah satunya melalui penentuan waktu kawin yang tepat untuk meningkatkan efisiensi reproduksi. Namun, hal tersebut sampai dengan saat ini masih belum tercapai dikarenakan para penangkar belum mampu mengenali tandatanda berahi yang tampak pada rusa sebagai penentu waktu kawin yang tepat. Salah satu tanda-tanda berahi nyata yang dapat menjadi indikator birahi adalah lendir serviks.

Lendir serviks mempunyai sifat reologi antara lain tingkat kekeruhan, spinnbarkeit, selain itu juga adanya tingkat kelimpahan lendir yang dapat di gunakan untuk 
mengindikasikan seekor ternak berada dalam siklus berahi. Pada siklus normal reologi lendir serviks akan berubah-ubah selama satu siklus estrus. Tingkat kelimpahan dan reologi lendir serviks ditentukan oleh keberadaan estrogen dan di hambat oleh progesteron. Kadar hormonal sendiri sangat dipengaruhi oleh nutrisi dari pakan yang di konsumsi. Nutrisi yang terserap oleh tubuh tersebut akan di gunakan untuk kebutuhan hidup pokok dan juga bereproduksi. Salah satu jenis nutrisi yang sangat di butuhkan seekor ternak adalah mineral. Unsur mineral dibutuhkan ternak dalam jumlah sedikit, namun mineral merupakan salah satu nutrisi yang harus tercukupi dalam tubuh ternak, terutama dalam berlangsungnya proses reproduksi.

Unsur mikro mineral sangat penting untuk aktivitas enzim dan hormon dalam tubuh. Keadaan tersebut dapat menurunkan kualitas reproduksi seekor ternak (Darmono, 2007). Banyak peneliti melaporkan bahwa mikro mineral sangat dibutuhkan untuk pertumbuhan dan pengoptimalan dari fungsi organ reproduksi. Defisiensi mineral zinc akan berakibat pada penurunan hormon steroid. Zinc akan berkaitan dengan progesteronestrogen yang termasuk ke dalam kategori hormon steoid dalam mempengaruhi proses reproduksi, sehingga jika terjadi defisiensi zinc (Zn) maka akan mengganggu terjadinya proses reproduksi (Akhtar et al., 2009). Selenium (Se) berperan dalam mempengaruhi terjadinya estrus pada ternak. Defisiensi Selenium akan menurunkan fertilitas pada ternak dan dapat mengakibatkan terjadinya anestrus (Akhtar et al., 2009). Adanya keadaan tersebut maka perlu dilakukan penelitian mengenai profil lendir servik rusa timor (Cervus timorensis) betina yang mendapat suplementasi mikro mineral pada tiap fase berahi. Evaluasi lendir serviks terhadap sifat-sifat reologi akan memberikan nilai kualitas yang dapat menentukan tingkat keberhasilan dalam proses penentuan berahi.

Tujuan dari penelitian tersebut adalah untuk mengetahui pengaruh mineral Zinc ( $\mathrm{Zn})$, Magnesium (Mg), Selenium (Se) terhadap kelimpahan, Spinnbarkeit dan tingkat kekeruhan lendir serviks rusa Timor. Manfaat dilaksanakanya penelitian ini adalah untuk meningkatkan Pengetahuan penangkar mengenai tanda-tanda berahi pada rusa khususnya tampilan profil lendir serviks.

\section{MATERI DAN METODE}

\section{Lokasi Penelitian}

Penelitian dilakukan pada tanggal 10 Maret - 31 Mei 2016 di penangkaran rusa Timor milik Bapak H. Yusuf Wartono, Desa Margorejo Kecamatan Dawe, Kabupaten Kudus, Jawa tengah.

Materi percobaan yang digunakan adalah Rusa Timor (Cervus timorensis) betina yang memiliki BCS $2-3,25$ dan poel 2 sebanyak 10 ekor. Rusa dalam kondisi yang sudah pernah melahirkan dan sehat fisik. Rusa yang digunakan memiliki panjang fase berahi yang berbeda-beda. Darah rusa dan lendir serviks sebagai objek yang diamati. Mineral yang digunakan meliputi Zinc (Zn), Selenium (Se) serta Magnesium $(\mathrm{Mg})$. Alat yang digunakan untuk pembuatan mineral blok meliputi alat pres mineral, ember, kuas, gelas, tongkat penekan, gelas ukur, timbangan, oven, blender, sendok. Proses sinkronisasi berahi menggunakan alat berupa pencetak spons, jarum, benang nilon spuit $10 \mathrm{cc}$, 
mangkok, ember, box pengering spons, sarung tangan (latex), aplikator sinkronisasi, dengan bahan berupa cairan MPA (Medroxy Progesterone Acetat) KY Jell dan alkohol. Alat yang digunakan untuk mengambil data lendir meliputi senter penerang, spekulum, kateter, KY Jell, beker glass tissue, jangka sorong untuk mengukur nilai spinnbarkeit, dan tabel skoring.

\section{Pembuatan Mineral Blok}

Semua bahan pakan yang akan digunakan ditimbang sesuai dengan komposisi yang tertera pada tabel 1, setelah semua bahan pakan ditimbang, kemudian dicampur sampai homogen dengan penambahan air sebanyak 70 $\mathrm{ml}$.

Tabel 1. Komposisi dan persentase mineral blok

\begin{tabular}{clc}
\hline No. & \multicolumn{1}{c}{ Bahan } & Persentase \\
\hline 1. & Molases & $----\%$---- \\
2. & Bekatul & 35 \\
3. & Bungkil Kedelai & 10 \\
4. & Onggok & 6,9 \\
5. & Garam & 6 \\
6. & Vitamin & 0,04699 \\
7. & Mineral & 2 \\
& 1. Premix & 0,05 \\
& $2 . \mathrm{Mg}$ & 0,003 \\
& $3 . \mathrm{Zn}$ & 0,00001 \\
\hline & $4 . \mathrm{Se}$ & 100 \\
\hline
\end{tabular}

Bahan pakan yang sudah tercampur homogen dimasukan kedalam alat cetak mineral. Mineral dicetak hingga berbentuk tabung. Mineral yang tercetak dioven pada suhu $59^{\circ} \mathrm{C}$ selama 48 jam, sampai mineral mengeras.

\section{Sinkronisasi Birahi}

Pelaksanaan sinkronisasi birahi diawali dengan pembuatan spons vagina dengan ketebalan $4 \mathrm{~cm}$. MPA (Medroxy Progesterone Acetate) yang sudah di encerkan dengan metanol dengan perbandingan $20 \mathrm{mg} / \mathrm{ml}$ ditambahkan pada spons vagina. Spons dikeringkan selama 48 jam pada box pengering. Implan spons vagina dilakukan pada rusa dengan cara sterilisasi aplikator dengan alkohol, mengoleskan KY Jell pada aplikator, sterilisasi vulva, pada spons diberikan betadin salep. Spons dimasukan pada aplikator lalu di implankan ke vagina secara hati-hati.

\section{Pengambilan Lendir Serviks}

Pengambilan lendir dilakukan dalam 8 titik waktu dengan waktu pengambilan data meliputi setelah pelepasan implan MPA (asumsi diestrus), 24 jam setelah pelepasan implan MPA (asumsi proestrus), 72 jam, 82 jam, 96 jam, 108 jam, 120 jam setelah pelepasan implan MPA (asumsi estrus) dan 144 jam (hari ke-6) setelah pelepasan implan MPA (asumsi metestrus). Lendir diambil dengan membuka vulva dengan speculum, lendir serviks disedot dengan kateter. Untuk mengukur nilai spinnbarkeit, lendir diletakan pada jari telunjuk dan jempol tangan, lendir direnggangkan hingga membentuk benang elastis sampai putus. Benang yang terbentuk kemudian diukur nilainya dengan jangka sorong. Nilai kelimpahan dan tingkat kekeruhan diamati melalui sistem skoring. Berikut adalah penentuan skor pada kelimpahan dan tingkat kekeruhan lendir serviks:

Skor 1 : lendir sedikit, hanya terdapat 
di cincin serviks.

Skor 2 : Lendir sedikit tetapi terlihat sampai dinding vagina.

Skor 3 : Lendir cukup banyak, terlihat menggantung di vulva.

Skor 4 : Lendir terlihat melimpah, menggantung di vulva dan sekitar pangkal ekor.

Skor 5: Lendir terlihat melimpah, menggantung di bagian vulva sampai paha bagian belakang.

Tingkat kekeruhan lendir serviks diamati melalui sistem skoring berikut:

Skor 1 : Keruh dan kental

Skor 2 : Keruh dan Cair

Skor 3 : Transparan dan kental

Skor 4 : Transparan dan cair

Data yang diperoleh di analisis menggunakan Mann Whitney U Test pada data kelimpahan dan tingkat kekeruhan lendir serviks serta T-test pada nilai spinnbarkeit.

Perlakuan yang dicobakan adalah :

T0 : Tanpa Suplementasi mineral (kontrol).

T1 : Pemberian suplementasi mineral Zinc $(\mathrm{Zn})$, Selenium (Se) dan Magnesium $(\mathrm{Mg})$.

\section{Analisis Data}

Kelimpahan lendir dan tingkat kekeruhan lendir serviks akan di uji menggunakan uji Mann Whitney U- Test denganrumussebagaiberikut :

$$
\mathrm{U}=n 1 . n 2+\frac{n 2(n 2+1)}{2}+\sum R
$$

Keterangan :

$\mathrm{U}:$ Statistik uji

$\mathrm{R}$ : Jumlah rank sampel

$\mathrm{n} 1$ : Banyaknya anggota sampel 1

n2 : Banyaknya anggota sampel 2
Pengolahan data yang diperoleh menggunakan uji Mann Whitney U- Test yang dihitung menggunakan metode hitung di SPSS. Nilai hasil pengamatan Spinnbarkeit lendir di uji menggunakan uji statistik Indepen- dent Sample $\mathrm{t}$ test, dan dihitung dengan rumus:

$$
\mathrm{t}=\frac{\bar{X}_{1}-\bar{X}_{2}}{\sqrt{\frac{\mathrm{S}_{1^{2}}}{\mathrm{n}_{1}}+\frac{\mathrm{S}_{2^{2}}}{\mathrm{n}_{2}}}}
$$

Keterangan :

$\mathrm{t} \quad$ : Nilai t hitung

$\mathrm{S}_{1}$ : Varians kelompok ke-1

$\bar{X}_{2}$ : Nilai rata-rata skor kelompok atas

$\bar{X}_{2}$ : Nilai rata-rata skor kelompok bawah

$\mathrm{S}_{2} \quad$ : Varians kelompok ke-2

n1 : Banyaknya subjek pada kelompok ke 1

n2 : Banyaknya subjek pada kelompok ke-2

Pengolahan data yangujimenggunakan

uji independent sample $\mathrm{t}$ test dilakukan menggunakan SPSS. 
HASIL DAN PEMBAHASAN

\section{Tingkat Kelimpahan Lendir Serviks}

Berdasarkan hasil pengamatan kelimpahan lendir serviks diketahui bahwa materi yang digunakan dalam penelitian memiliki panjang fase berahi yang berbedabeda setiap individu. Data pengamatan pada kelimpahan lendir menunjukan bahwa skor kelimpahan lendir serviks T0 pada fase diestrus memiliki nilai yang lebih tinggi dibandingkan dengan $\mathrm{T} 1$. Titik fase proestrus hingga fase estrus ke 3, skor kelimpahan lendir pada T1 lebih tinggi dibandingkan dengan T0. Nilai skor kelimpahan lendir serviks T0 kembali lebih tinggi pada titik pengambilan data fase metestrus 1 dan metestrus 2. Hal tersebut diperjelas pada Tabel 2. Data rata-rata skoring nilai kelimpahan lendir serviks rusa Timor betina pada tiap fase berahi.

Tabel 1. Data rata-rata skoring kelimpahan lendir servis

Titik Pengambilan per Fase

Kode

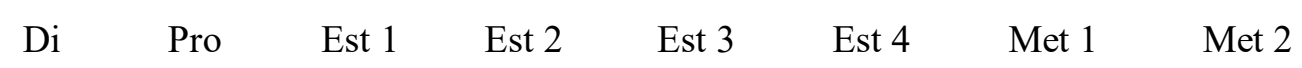

\begin{tabular}{lllllllll}
\hline T0R1 & 2 & 1 & 2 & 1 & 1 & 1 & 1 & 2 \\
T0R2 & 2 & 3 & 2 & 1 & 2 & 1 & 1 & 1 \\
T0R3 & 2 & 2 & 1 & 2 & 1 & 1 & 1 & 1 \\
T0R4 & 3 & 2 & 2 & 1 & 2 & 1 & 2 & 1 \\
T0R5 & 2 & 3 & 1 & 1 & 1 & 1 & 1 & 1 \\
T1R1 & 2 & 2 & 1 & 1 & 1 & 1 & 1 & 1 \\
T1R2 & 2 & 3 & 4 & 2 & 2 & 1 & 1 & 1 \\
T1R3 & 1 & 3 & 2 & 2 & 1 & 1 & 1 & 1 \\
T1R4 & 1 & 2 & 2 & 1 & 2 & 1 & 1 & 1 \\
T1R5 & 2 & 3 & 3 & 4 & 4 & 1 & 1 & 1 \\
\hline
\end{tabular}

Berdasarkan hasil uji statistik menyebabkan timbulnya berahi yang lemah, menggunakan Mann Whitney U-test silent heat, anestrus, dan kawin berulang. menunjukan bahwa suplementasi mineral $\mathrm{Zn}$, Abidin et al. (2012) memperkuat bahwa Se dan $\mathrm{Mg}$ tidak berbeda nyata $(\mathrm{P}>0,05)$ antara penampilan berahi yang kurang jelas dapat T0 dan T1 pada tingkat kelimpahan lendir dikarenakan oleh asupan pakan yang kurang serviks rusa timor tiap fase berahi. Hal tersebut karena kandungan mineral pakan yang memenuhi kebutuhan sehingga mengganggu diberikan pada rusa sudah memiliki kandungan mineral yang cukup tinggi. Oleh karena itu tingkat kelimpahan lendir serviks dari T0 juga akan pengalami peningkatan yang sama dengan T1 pada saat berada di fase estrus. Prihatno et al.(2013) menyatakan bahwa pakan merupakan faktor yang sangat berpengaruh terhadap reproduksi, kekurangan protein sintesa dan regulasi hormon-hormon reproduksi yang sangat berperan dalam penampilan gejala berahi ternak betina.

Keberadaan $\mathrm{Zn}$ dan $\mathrm{Mg}$ dapat meningkatkan jumlah folikel pada akhir fase luteal. Adanya kedua mineral tersebut dapat meningkatkan perkembangan folikel de graaf. Semakin banyak dan besar ukuran Folikel de graaf maka keberadaan sel theca di dalamnya 
juga akan semakin meningkat. Sel techa berfungsi untuk menghasilkan estrogen. Oleh karena itu keberadaan $\mathrm{Zn}$ dan $\mathrm{Mg}$ dapat memicu sekresi estrogen melalui perkembangan folikel de graaf. Maaty et al., (2013) menyatakan bahwa suplementasi Zinc dan Magnesium terbukti meningkatkan jumlah folikel pada akhir fase luteal, sehingga sekresi estrogen meningkat pada fase luteal. Selain $\mathrm{Zn}$ dan $\mathrm{Mg}$, keberadaan selenium memiliki peran untuk merangsang poliferase sel dari beberapa folikel kecil. Prasdini et al. (2014) menyatakan bahwa selenium juga berperan dalam merangsang poliferase sel dari beberapa folikel kecil yang akan mendorong produksi cairan folikel dan estrogen, sehingga dapat mempengaruhi jumlah sekresi lendir serviks.

Pada saat rusa berada pada fase berahi kadar estrogen dalam darah akan meningkat. Meningkatnya kadar estrogen dalam darah rusa betina akan memicu keberadaan hormon adrenalin dan oksitosin. Hormon adrenalin akan meningkatkan tekanan darah sehingga cairan ke sel goblet juga akan meningkat yang di- akibatkan oleh adanya peningkatan sel sitoplasma. Adanya peningkatan sel sitoplasma maka ukuran sel goblet akan membesar dan mengalami penipisan dinding, pada keadaan ini hormon oksitosin akan mempercepat proses pecahnya sel goblet. Hal lain yang di timbulkan adanya hormon oksitosin adalah relaksasi uterus khususnya pada bagian serviks. Keadaan tersebut menimbulkan ada- nya peningkatan sekresi lendir pada serviks. Dalam penelitian Syahruddin et al. (2013) menyatakan bahwa keberadaan hormon adrenalin dapat mempengaruhi peningkatan aktivitas jantung, pernafasan dan sirkulasi darah perifer, sehingga dapat terjadi peningkatan suplai darah ke organ-organ tertentu. Hormon lain yang berpengaruh terhadap sekresi lendir serviks adalah oksitosin. Keberadaan hormon oksitosin berpengaruh pada sekresi lendir serviks, karena hormon oksitosin memiliki fungsi untuk merelaksasi serviks sehingga saat ternak berahi serviks akan membuka sebagai jalan keluarnya lendir. Suharto (2003) memperkuat bahwa saat terjadi peningkatan estrogen dalam darah, maka akan terjadi peningkatan aktivitas sel-sel goblet dan terjadi penimbunan air pada sitoplasma. Akibat tekanan cairan sitoplasma yang semakin meningkat maka dinding sel goblet akan pecah dan mengeluarkan lendir ke dinding serviks, semakin tinggi kadar hormon estrogen maka semakin banyak sel - sel goblet yang pecah dan akan mencairkan kripta-kripta pada mucus.

\section{Tingkat Kekeruhan Lendir Servik}

Tingkat kekeruhan lendir serviks merupakan salah satu sifat reologi lendir serviks yang dapat dijadikan sebagai kualifikasi menilai seekor ternak berada dalam fase berahi. Berdasarkan hasil pengamatan diketahui bahwa skor tingkat ke- keruhan lendir serviks T1 pada titik fase diestrus, proestrus, estrus 2 hingga estrus 4 lebih tinggi di- bandingkan T0. Pada titik pengambilan data estrus 1, skor T1 lebih rendah dibandingkan skor T0 (Tabel 3). Hal tersebut terjadi karena kadar estrogen pada awal fase estrus belum cukup tinggi sehingga tampilan kekeruhan lendir dari rusa timor sendiri masih belum terlihat nyata. Maaty et al. (2013) menyatakan bahwa estrogen mulai tersekresikan pada awal fase luteal, tetapi keberadaanya paling tinggi saat berada di akhir fase luteal. 
Berdasarkan hasil uji statistik tingkat kekeruhan lendir serviks rusa timor betina tiap titik waktu pengambilan data menggunakan Mann Whitney U-Test di peroleh hasil bahwa suplementasi Zinc (Zn), Selenium (Se) dan
Magnesium $(\mathrm{Mg})$ tidak berbeda nyata $(\mathrm{P}>0,05)$ pada tingkat kekeruhan lendir serviks rusa timor pada tiap titik waktu pe- ngambilan data di setiap fase dalam siklus berahi.

Tabel 3. Skor rata-rata tingkat kekeruhan lendir serviks pada setiap titik pengambilan fase berahi

\begin{tabular}{lccc}
\hline \multicolumn{1}{c}{ Fase } & $\begin{array}{c}\text { Setelah Pencabutan } \\
\text { Spons }\end{array}$ & \multicolumn{2}{c}{ Perlakuan } \\
\cline { 2 - 4 } & & T0 & T1 \\
\hline & ---- jam ---- & 1,2 & 1,7 \\
Diestrus & 0 & 2,2 & 2,7 \\
Proestrus & 24 & 1,6 & 1,25 \\
Estrus 1 & 72 & 1,4 & 2,4 \\
Estrus 2 & 84 & 1,8 & 2,4 \\
Estrus 3 & 96 & 1 & 1,7 \\
Estrus 4 & 108 & 1 & 1 \\
Metestrus 1 & 120 & 1 & 1 \\
Metestrus 2 & 144 & & \\
\hline
\end{tabular}

Tingkat kekeruhan lendir yang tidak perbeda nyata tersebut erat kaitanya dengan kelimpahan lendir serviks yang dihasilkan selama siklus estrus. Lendir serviks yang dihasilkan oleh sel goblet memiliki kandungan enzym lisosim. Enzim ini memiliki prinsip kerja merusak dinding sel bakteri pada serviks. Oleh karena itu tingkat kelimpahan dari lendir serviks berbanding lurus dengan tingkat kekeruhan lendir. Semakin tinggi lendir yang disekresikan maka semakin tinggi kadar enzim losozym, sehingga jumlah flora dan fauna bakteri dalam serviks akan menurun dan lendir akan terlihat lebih cair dan transparan. Maaty et al., (2013) menyatakan bahwa suplementasi Zinc dan Magnesium dapat meningkatkan aktivitas enzim lisozim pada ternak betina selama fase estrus. Kruse et al., (2000) memperkuat bahwa aktifitas bakteri dalam organ reproduksi sangat dikendalikan oleh keberadaan enzim lisozym sehingga semakin tinggi lisozym maka aktifitas bakteri akan menurun yang dapat membuat lendir serviks mencadi transparan saat terjadinya estrus.

Keberadaan mineral Zinc, Selenium dan Magnesium sangat berpengaruh terhadap perkembangan folikel selama fase estrus. Fungsi folikel de graaf adalah sebagai penghasil estrogen selama berlangsungnya siklus berahi. Tingginya kandungan $\mathrm{Zn}$ pada pakan yang di konsumsi oleh rusa T0 dapat memicu sekresi lendir yang transparan dan cair, sehingga tidak ada perbedaan nyata terhadap tingkat kekeruhan yang dihasilkan antara kedua perlakuan tersebut. Dalam Maaty et al., (2013) menyatakan bahwa suplementasi Zn dan Mg terbukti meningkatkan jumlah folikel pada akhir fase luteal, sehingga sekresi estrogen meningkat pada fase tersebut. Prasdini et al., (2014) memperkuat bahwa selenium dapat menginisiasi pembentukan folikulo- genesis pada ovarium. Selenium juga berperan dalam merangsang proses poliferase sel dari beberapa folikel kecil yang akan 
mendorong produksi cairan folikel dan estrogen.

Fungsi lain dari keberadaan Zinc yang harus tercukupi dalam tubuh ternak adalah membantu proses metabolisme kolesterol sebagai perkusor pembentukan estrogen. Oleh karena itu semakin tinggi kadar Zinc pada pakan yang dikonsumsi maka kolesterol yang dihasilkan oleh tubuh ternak akan tercukupi untuk proses metabolisme hormon steroid. Dalam penelitian Hernawan et al. (2016) menyatakan bahwa peningkatan Zinc dalam darah diakibatkan oleh suplementasi Zinc dalam ransum. Keberadaan mineral tersebut me- miliki peran penting dalam proses metabolisme kolesterol yang merupakan bahan baku sintesis hormon steroid selain itu zinc juga berperan aktif dalam proses pembelahan sel.

Khairi et al. (2014) menyatakan bahwa Zink (Zn) merupakan jenis mikro mineral yang memiliki peran penting dalam proses metabolisme kolesterol. Kolesterol merupakan bahan baku sintesis hormon steroid (reproduksi). Zink juga terlibat dalam beberapa reaksi enzimatik yang terkait dengan metabolisme kar- bohidrat, sintesis protein, dan metabolisme asam nukleat. Fungsi zink didalam sel yaitu sama seperti fungsi gonad yang berparan aktif dalam pertumbuhan dan pembelahan sel, sehingga kekurangan Zn mampu mempengaruhi fungsi reproduksi.

Kekeruhan lendir dipengaruhi oleh kerja hormonal dalam tubuh ternak yang akan memicu kerjanya sel-sel pada organ reproduksi terutama serviks sebagai penghasil lendir. Tingkat kekeruhan pada lendir serviks seekor ternak di pengaruhi oleh kondisi kesehatan organ reproduksi penghasilnya dan juga keberadaan bakteri yang ada pada dinding serviks. Dalam Verma et al., (2014) menyatakan bahwa tingkat kekeruhan lendir serviks dipengaruhi oleh tingkat kesehatan dari organ reproduksi penghasil lendir, apabila organ reproduksi dalam keadaan kurang baik, maka lendir yang di hasilkan cenderung keruh karena kotor lendir serviks erat kaitanya dengan kelancaran proses fertilisasi, karena semakin cair lendir pada masa estrus maka akan semakin mudah spermatozoa menembusnya.

Oleh karena itu pada saat ternak mengalami puncak berahi sangat diperlukan keadaan lendir yang memiliki tingkat kecairan yang lebih tinggi. Mardiati (2003) menyatakan bahwa pada fase estrus lendir yang bersifat cair terdapat ruang celah. Ruang tersebut merupakan celah-celah yang cukup luas untuk dilewati spermatozoa sebagai penunjang proses fertilisasi.

\section{Nilai Spinnbarkeit}

Nilai spinnbarkeit merupakan upaya untuk mengetahui seberapa tinggi kemungkinan lendir yang berserat yang memungkinkan membentuk benang dan elastisitas. Berdasarkan hasil pengamatan dapat diketahui bahwa nilai spinnbarkeit lendir serviks pada T0 cenderung lebih tinggi pada setiap titik pengambilan, khususnya pada titik pengambilan fase estrus. Hal tersebut tersebut dapat dilihat pada tabel 4. Tingginya nilai spinnbarkeit pada T0 (kontrol) diakibatkan pakan yang di konsumsi sudah mengandung mineral Zinc (Zn), Selenium (Se) dan Magnesium (Mg) yang cukup tinggi sehingga lendir yang dihasilkan akan memiliki tingkat elastisitas yang tidak jauh beda dengan $\mathrm{T} 1$. 
Berdasarkan hasil uji menggunakan $t$ test pada titik pengambilan data diestrus, proestrus, estrus 2, estrus 3 , estrus 4 , metestrus 1 , metestrus 2 serta hasil uji statistik Mann
Whitney pada titik estrus 1 pemberian mineral tidak berbeda nyata terhadap nilai spinnbarkeit T0 dan T1.

Tabel 4. Rata-rata nilai spinnbarkeit lendir serviks pada setiap titik pengambilan fase berahi

\begin{tabular}{lccc}
\hline \multicolumn{1}{c}{ Fase } & $\begin{array}{c}\text { Setelah Pencabutan } \\
\text { Spons }\end{array}$ & \multicolumn{2}{c}{ Perlakuan } \\
\cline { 3 - 4 } & & T0 & T1 \\
& ----- jam ----- & ----------- cm ---------- \\
Diestrus & 0 & 2,21 & 0,72 \\
Proestrus & 24 & 1,54 & 1 \\
Estrus 1 & 72 & 2,99 & 2,14 \\
Estrus 2 & 84 & 1,66 & 1,24 \\
Estrus 3 & 96 & 2,92 & 1,84 \\
Estrus 4 & 108 & 1,52 & 0,58 \\
Metestrus 1 & 120 & 0,66 & 1,24 \\
Metestrus 2 & 144 & 2 & 1,91 \\
\hline
\end{tabular}

Tingginya nilai spinnbarkeit pada T0 karena tingginya kandungan mineral $\mathrm{Zn}$, Se dan $\mathrm{Mg}$ dalam pakan yang dikonsumsi oleh T0, sehingga nilai spinnbarkeit yang dihasilkan oleh T0 cenderung lebih tinggi dibandingkan nilai spinnbarkeit pada T1. Pakan yang di makan ternak sebagian besar digunakan untuk sintesa hormon reproduksi. Dalam hal ini pakan yang sudah mengandung $\mathrm{Zn}, \mathrm{Se}$ dan $\mathrm{Mg}$ yang tinggi akan meningkatkan kandungan mineral darah yang berdampak pada peningkatan per- kembangan folikel de graaf. Semakin tinggi jumlah folikel yang dihasilkan maka semakin tinggi sekresi hormon estrogen dalam tubuh ternak.

Semakin tinggi estrogen dalam darah rusa maka akan memicu keberadaan hormon adrenalin dan oksitosin yang dapat berperan dalam peningkatan aktivitas sel goblet sebagai penghasil lendir. Dalam fase estrus sekresi lendir yang meningkat diikuti oleh peningkatan kandungan musin didalamnya. Kandungan protein terlarut yang tersusun oleh albumin dan imonoglobulin serta musin yang juga mengandung glikoprotein yang akan membentuk jaringan benang-benang padat pada lendir, sehingga nilai spinnbarkeit akan meningkat. Berdasarkan Tabel 4, nilai spinnbarkeit meningkat saat berada di fase estrus. Adinegara (2006) yang menyatakan bahwa jumlah lendir terbanyak adalah saat terjadi ovulasi dengan kandungan air, garam organik dan protein serta musin. Komponen utama dari protein terlarut penyusun lendir serviks adalah albumin dan imonoglobulin sedangkan musin lendir serviks merupakan suatu glikoprotein yang mengandung ba- nyak karbohidrat. Glikoprotein tersebut berpengaruh terhadap nilai viskositas lendir serviks dan berperan penting dalam transportasi sperma. Hal lain yang mempengaruhi lebih tingginya nilai spinnbarkeit pada T0 (kontrol) adalah tingginya kandungan protein pakan yang di konsumsi oleh rusa-rusa T0. Protein merupakan salah satu prekursor hormon gonadal (estrogen). 
Tsiligianni et al. (2011) menyatakan bahwa nilai spinnbarkeit dipengaruhi oleh keberadaan hormon gonad, nilai nya akan tinggi pada sekitar periode pre ovulasi dan menjadi lebih rendah pada akhir estrus. Faktor yang mempengaruhi tingkat keenceran lendir adalah adanya perubahan pola siklik atau kandungan dari lendir serviks yang keluar.

Spinnbarkeit merupakan salah satu indikator pengukuran lendir serviks untuk menentukan status berahi seekor ternak. Hal tersebut sesuai dengan pendapat Mardiati (2016) yang menyatakan bahwa spinnbarkeit adalah istilah yang dipakai untuk menguraikan ciri lendir serviks yang berserat, kemungkinan terbentuknya benang. Berdasarkan Tabel 4. dapat diketahui bahwa nilai spinnbrkeit mulai meningkat pada awal fase estrus dan mengalami penurunan pada titik fase metestrus pertama. Tsiligianni et al. (2011) menyatakan bahwa nilai spinnbarkeit bervariasi pada sepanjang siklus estrus. Pada awal sebuah siklus normal, spinnbarkeit bernilai rendah, bebehari sebelum ovulasi nilainya meningkat mencapai puncak hingga tepat sebelum terjadinya perubahan suhu tubuh. Nilainya, kemudian menurun dengan cepat hingga mencapai nilai terendah pada fase luteal, hal tersebut disebabkan karena prbedaan jumlah hormon estrogen pada setiap fase-fasenya.

Keberadaan hormon estrogen telah diketahui memicu peningkatan sekresi musin dan plasma serviks. Pada masa ovulasi sekresi protein terlarut akan menurun dan musin meningkat sehingga nilai viskositas menurun dan nilai spinnbarkeit lendir meningkat. Kandungan dasar lendir serviks adalah berupa protein terlarut dan musin. Pada kadar Zinc yang tinggi maka akan meningkatkan kadar musin dan protein terlarut dalam lendir. Komponen utama dari protein terlarut adalah albumin dan imono globulin.

Musin lendir serviks merupakan suatu glikoprotein yang mengandung banyak karboidrat, glikoprotein tersebut akan berpengaruh pada viskositas lendir yang keluar. Hal tersebut sependapat dengan Diketahui sekresi musin meningkat saat berada pada masa ovulasi. Masa ovulasi lendir serviks yang keluar adalah lendir tipe e, lendir ini mengandung sedikit persilangan pada matriknya sehingga menurunkan nilai viskositas dan meningkatkan nilai spinnbarkeit. Nilai spinnbarkeit juga di pengaruhi oleh adanya kumpulan micelle yang berbentuk paralel menyerupai batang saat fase ovulasi dan terpecah membentuk jaringan padat saat menginjak fase luteal. Hal tersebut diperkuat oleh Mardiati (2003) bahwa perubahan pola siklik protein dipengaruhi oleh produksi hormon seks dalam tubuh. Estrogen yang merupakan hormon reproduksi betina akan menurukan kadar protein terlarut, sehingga pada fase estrus lendir akan semakin cair.

Tingginya tingkat keenceran lendir pada fase estrus berkaitan dengan mudahnya lendir di lewati oleh spermatozoa untuk melakukan proses fertilisasi. Hal tersebut sependapat dengan Mardiati (2003) bahwa pada awal siklus normal, spinnbarkeit lendir bernilai rendah. Beberapa hari sebelum ovulasi nilainya meningkat mencapai puncak hingga tepat sebelum terjadinya perubahan suhu tubuh. Kemudian nilainya menurun dengan cepat hingga mencapai nilai terendah pada masa fase luteal. Komponen dengan viskositas rendah atau komponen tipe e (estrogenik) yang bersifat encer dan banyak. 
Komponen tipe estrogenik mengandung rantai makro molekul musin yang tersusun dalam struktur miceller dengan ruang-ruang di antara micel. Ruang tersebut merupakan celahcelah yang cukup luas untuk dilewati spermatozoa sebagai pe- nunjang proses fertilisasi.

\section{KESIMPULAN}

Berdasarkan hasil penelitian yang dilakukan dapat disimpulkan bahwa suplementasi mineral Zink (Zn), Selenium (Se) dan Magnesium $(\mathrm{Mg})$ tidak berpengaruh nyata terhadap kelimpahan, tingkat keke- ruhan dan nilai spinnbarkeit pada lendir serviks rusa timor betina selama siklus estrus. Hal tersebut terjadi karena kadar Zinc (Zn) dalam pakan yang diberikan sudah tinggi, sehingga tampilan profil lendir serviks pada T0 tidak berbeda dengan $\mathrm{T} 1$.

\section{UCAPAN TERIMAKASIH}

Terimakasih kepada Direktorat Penelitian dan Pengabdian Kepada Masyarakat, Kepada Direktorat Jenderal Pendidikan Tinggi, Kementrian Riset dan Teknologi Republik Indonesia yang telah mendukung kegiatan penelitian ini melalui dana penelitian fundamental 2016. Kepada Bapak Alam Sriwijaya, S. Pt. Yang memberi arahan mengenai proses sinkronisasi berahi dan kebutuhan alat yang tepat dalam proses penelitian ini. Kepada Lilik Kismiyanto, S. Pt, M. Si.yang mem- berikan arahan terkait penggunaan mineral Zinc (Zn), Selenium (Se) dan Magnesium (Mg). Terimakasih juga saya ucapkan kepada Bapak Kelik Isharyudhono, S. T. yang memberi arahan mengenai pembuatan alat pres mineral blok dan proses pembuatan mineral blok.

\section{DAFTAR PUSTAKA}

Adinegara, R. 2006. Penambahan etinil estradiol pada induksi ovulasi menggunakan klomifen sitrat: Pengaruh terhadap nilai rheologi lendir serviks dan ketebalan endometrium. Universitas Diponegoro, Semarang.

Hafizuddin, W. N. Sari, T. N. Siregar dan Hamdan. 2011. Persentase berahi dan kebuntingan kam- bing peranakan ettawa (PE) setelah pemberian beberapa hormon prostaglandin komer- sial. Universitas Almuslim, Bireuen. Jur. Ked. Hew. 5 (2).

Iskandar, F., E. T. Setiatin dan Sutiyono. 2015. Perubahan vulva dan peningkatan sekresi lendir serviks sebagai indikator berahi pada kambing kejobong betina yang kesuburanya diting- katkan menggunakan ekstrak hipofisa. Jur. Agromed. 33 (2) : 28-34.

Khairi, F., A. Muktiani dan Y.S. Ondho. 2014. Pengaruh suple- mentasi vitamin E, mineral selenium dan zinc terhadap konsumsi nutrien, produksi dan kualitas semen sapi simental. Jur. Agripet. 14 (1) : 6-16.

Kruse, W. E., I. Botz, S. Pohl, G. Rohr dan T. Strowitzki. 2000. Anti- microbial activity of human cervical mucus. University of Heidelberg. Germany. Jour. Hum. Reprod. 15 (4): 778-784.

Maaty, A. M. A. E., A. M. Ibrahim, O. H. Ezzo. 2013. Influence of mineral supplementation on oxidative stress, ovarian folli- cles growth and reproductive hormone concentration in cycle Arab mares. Agriculture Research Centre, Dokki. Jour. of Reprod. 2 (1): 8-14. 
Mardiati, S. M. 2003. Kadar garam Na lendir servik serta kadar garam $\mathrm{Na}$ dan $\mathrm{K}$ lendir mulut pada berbagai struktur daun pakis (tes ferning). Magister Ilmu Biomedik. Universitas Diponegoro, Semarang.

Prihatno, A. Kusumawati., N. W. K. Karja dan B. Sumiarto. 2013. Profil Biokimia Darah Pada Sapi Perah Yang Mengalami Kawin Berulang. Jur. Ked. Hewan. 7 (1) : 29-31.

Suharto, K. 2003. Penampilan potensi reproduksi sapi perah friesian holstein akibat pemberian kualitas ransum berbeda dan infusi larutan iodium povidon 1\% intra uteri. Program Studi Magister Ilmu Ternak Program Pasca
Sarjana Fakultas Peter- nakan Universitas Diponegoro, Semarang.

Verma, K. K., S. Prasad, A. Kuma - resan, T.K. Mohanty, S. S. Layek, T. K. Patbandha dan S. Chand. 2014. Characteri- zation of physio-chemical properties of cervical mucus in relation to parity and conception rate in murrah buffaloes. Junagadh Agricultural University. India. Jour. Vet. 7 (5).

Widiyono, I., P. P. Putro, Sermin, P. Astuti dan C. N. Arin. 2011. Kadar estradiol dan progesteron serum, tampilan vulva dan sitologi apus vagina kambing Bligon selama siklus birahi. Jur. Vet. 12 (4) : 263-268. 